\title{
Thermal Effects on Reverse Transcription: Improvement of Accuracy and Processivity in cDNA Synthesis
}

BioTechniques 30:1074-1084 (May 2001)

\author{
Christine M. Malboeuf, \\ Seth J. Isaacs, Nancy H. Tran, \\ and Baek Kim \\ University of Rochester Medical \\ Center, Rochester, NY, USA
}

\section{INTRODUCTION}

Molecular analysis of RNA molecules relies heavily on reverse transcription, which preserves molecular information of chemically unstable RNAs as stable DNAs that can be used in various analytical methodologies. The synthesized DNA molecules are often further amplified by PCR, which greatly enhances the efficiency of RNA analysis $(7,9)$. RT-PCR has been widely used for various RNA analyses such as diagnostic detection (17-19,23), genotyping of various viral RNAs in infected samples $(5,28)$, quantitation of gene expression (QRT-PCR) (1,6,7,24,25), and construction of cDNA libraries from various biological organisms (20).

Reverse transcription of RNA is catalyzed by retroviral DNA polymerases called reverse transcriptases (22). Unlike other DNA polymerases, reverse transcriptases synthesize DNA from both DNA and RNA templates. All retroviral reverse transcriptases, such as murine leukemia virus (MuLV) and human im munodeficiency virus type 1 (HIV-1), lack a $3^{\prime} \rightarrow 5^{\prime}$ proofreading exonuclease, which contributes to the accuracy of other DNA polymerases (26). For this reason, reverse transcription is highly error prone. Mutations created during the reverse transcription step of the RT-PCR are delivered to the final products to be analyzed; this interferes with the correct analysis of RNA molecules.

Another deleterious aspect of reverse transcription is its use of RNA as a template. RNA can form various types of secondary structures that inter- fere with processive DNA synthesis $(4,15,16)$. RNA molecules containing secondary structures, called pause sites, are difficult to extend to full-length DNA products. Indeed, accuracy and processivity of reverse transcription are key elements for the improvement of RNA analyses.

In this study, we report that an increase in temperature greatly enhances both the accuracy and the processivity of reverse transcription, with minimum impact on the DNA polymerase activity of reverse transcriptases. The mechanisms of thermal effects on the fidelity and the processivity of reverse transcriptases and the possible applications of this finding are discussed.

\section{MATERIALS AND METHODS}

\section{Purification of MuLV and HIV-1 Reverse Transcriptase Proteins}

Procedures for the purification of the hexahistidine-tagged MuLV reverse transcriptase were modified from our protocol, which was established for the purification of HIV-1 reverse transcriptase by $\mathrm{Ni}^{++}$chelation chromatography, which has been described previously (12). For expression of MuLV, we constructed a plasmid, pMuLVRT, that is a pET28 (Novagen, Madison, WI, USA) containing a full-length $\mathrm{MuLV}$ reverse transcriptase gene that was amplified from pMuLV (provided by Dr. M. Emerman, Fred Hutchinson Cancer Research Center, Seattle, WA, USA). The amplified MuLV reverse transcriptase 
gene was inserted into pET28a at its $N d e \mathrm{I}$ and EcoRI sites. MuLV reverse transcriptase, expressed from pMuLVRT, is fused at the N-terminus to six histidine residues. The buffers and reagents for the MuLV reverse transcriptase purification were obtained from Novagen. Expression of MuLV reverse transcriptase was induced by the addition of $0.1 \mathrm{mM}$ isopropyl- $\beta$-D-thiogalactoside to $1000 \mathrm{~mL} \log$ phase $E$. coli BL21 with pMuLVRT and grown in $2 \times$ YT to a $A_{600}$ of 0.5 in the presence of kanamycin $(30 \mu \mathrm{g} / \mathrm{mL})$. After incubation for $2 \mathrm{~h}$, cells were harvested by centrifugation, and the pellets were resuspended and frozen at $-70^{\circ} \mathrm{C}$ with $20 \mathrm{~mL} 1 \times$ binding buffer and 200 $\mu \mathrm{g} / \mathrm{mL}$ lysozyme. Frozen cells were thawed and lysed on ice for approximately $2 \mathrm{~h}$. The lysed cells were centrifuged at $27000 \times g$, and the supernatant solution was applied to a $\mathrm{Ni}^{++}$-charged His Bind ${ }^{\circledR}$ column (5 $\mathrm{mL})$. The resin was prepared by successive washes with deionized water, $1 \times$ charge buffer, and $1 \times$ binding buffer. All chromatographic steps were carried out at $4^{\circ} \mathrm{C}$ at a flow rate of $20 \mathrm{~mL} / \mathrm{h}$. Following the application of the crude supernatant solution, the column was washed with $1 \times$ binding buffer and $1 \times$ wash buffer. MuLV reverse transcriptase was eluted with $1 \times$ elute buffer. Fractions containing purified MuLV reverse transcriptase were analyzed by electrophoresis in a $12 \%$ SDS polyacrylamide gel. Fractions containing MuLV reverse transcriptase were combined and dialyzed against $50 \mathrm{mM}$ Tris- $\mathrm{HCl}$, $\mathrm{pH}$ 7.5, $1 \mathrm{mM}$ EDTA, $200 \mathrm{mM} \mathrm{NaCl}$, and $10 \%$ glycerol for $16 \mathrm{~h}$. The dialyzed MuLV reverse transcriptase fraction was further dialyzed against the same buffer containing $1 \mathrm{mM}$ dithiothreitol (DTT) for an additional $16 \mathrm{~h}$. In this protocol, the purity of MuLV reverse transcriptase was at least $95 \%$, estimated by the inspection of Coomassie ${ }^{\circledR}$ Blue-stained gels with previously purified reverse transcriptase proteins.

\section{Assays for DNA Polymerase Activity of MuLV Reverse Transcriptase}

RNA-dependent DNA polymerase (RDDP) activity of the purified reverse transcriptase enzyme was measured by a primer extension reaction (13). For comparison, we also used two commercially available MuLV reverse transcriptases (New England Biolabs, Beverly, MA, and Roche Molecular Biochemicals, Indianapolis, IN, USA). Purified and purchased MuLV reverse transcriptase proteins were incubated for $3 \mathrm{~min}$ at $37^{\circ} \mathrm{C}, 45^{\circ} \mathrm{C}, 55^{\circ} \mathrm{C}$, or $60^{\circ} \mathrm{C}$ in $20 \mu \mathrm{L}$ reaction mixture containing a 40-mer RNA template (5'-AAGCU UGGCUGCAGAAUAUUGCUAGCGGGAAUUCGGCGCG-3'; $25 \mathrm{nM})$ annealed to a 17-mer (5'-CGCGCCGAATTCCCGCT-3'; $10 \mathrm{nM}){ }^{32} \mathrm{P}-\mathrm{la}-$ beled at the $5^{\prime}$ end with T4 polynucleotide kinase (template:primer, 2.5:1), four dNTPs (250 $\mu \mathrm{M}$ each), 25 $\mathrm{mM}$ Tris- $\mathrm{HCl}, \mathrm{pH} 8.0,100 \mathrm{mM} \mathrm{KCl,} 2$ $\mathrm{mM}$ DTT, $5 \mathrm{mM} \mathrm{MgCl}_{2}$, and 0.1 $\mathrm{mg} / \mathrm{mL}$ bovine serum albumin. Reactions were terminated by the addition of $5 \mu \mathrm{L} 40 \mathrm{mM}$ EDTA, 99\% formamide. Reaction products were immediately denatured by incubation at $95^{\circ} \mathrm{C}$ for $3 \mathrm{~min}$ and analyzed by electrophoresis in $14 \%$ polyacrylamide-urea gels. RDDP activity was determined by the synthesis of 40-nucleotide-long fully extended products. Under this condition, the production of the fully extended primer was a linear function of the amount of enzyme and incubation time. We also used two purchased MuLV reverse transcriptases (from New England Biolabs and Roche Molecular Biochemicals) to compare the enzymatic activity of our MuLV reverse transcriptase.

\section{Misincorporation Assay}

Procedure for this assay has been previously described $(13,14)$. The deoxyoligonucleotide template-primer was prepared by annealing a 40-mer RNA template (5'-AAGCUUGGCUG CAGAAUAUUGCUAGCGGGAAUUCGGCGCG-3') to a 17-mer matched primer (5'-CGCGCCGAATTCCCG CT-3') or to a 16-mer G/T-mismatched primer (5'-CGCGCCGAATTCCCGT$\left.3^{\prime}\right){ }^{32} \mathrm{P}$ - labeled at the $5^{\prime}$ end. The $17-$ mer matched primer was also annealed to a 63-mer DNA template (5'-TAA TACGACTCACTATAGGGAGGAAG CTTGGCTGCAGAATATTGCTAGCGGGAATTCGGCGCG-3') for the reactions with the HIV-1 reverse transcriptase. Assay mixtures $(20 \mu \mathrm{L})$ con- tained $10 \mathrm{nM}$ template/primer, MuLV reverse transcriptase ( 15 or $25 \mathrm{nM})$, and three or four dNTPs ( $250 \mu \mathrm{M}$ each) in the same buffer as described above. Reactions were incubated at $37^{\circ} \mathrm{C}, 45^{\circ} \mathrm{C}$, $55^{\circ} \mathrm{C}$, or $60^{\circ} \mathrm{C}$ for $3 \mathrm{~min}$ and terminated by the addition of $5 \mu \mathrm{L} 40 \mathrm{mM}$ EDTA, 99\% formamide. HIV-1 reverse transcriptase $(10 \mathrm{nM})$ was also used in this assay by RNA template encoding a 1.7kb-long HIV-1 reverse transcriptase sequence, annealed to $32 \mathrm{P}$-labeled 3305 primer (14). This 1.7-kb HIV-1 RNA template was synthesized by T7 RNA polymerase-catalyzed transcription of pBK8 $(12,14)$, which encodes the HIV1 reverse transcriptase gene between the HindIII and EcoRI sites of pBluescript $^{\circledR}(+)$ (Stratagene, La Jolla, CA, USA). The transcribed RNA was purified by ethanol precipitation and annealed to a 32P-labeled 21-mer (3305 reverse transcriptase primer) complementary to nucleotides encoding amino acids from 239 to 246 of HIV-1 reverse transcriptase. Otherwise, reaction conditions were the same as described above. The extension reactions were initiated by adding the trap mixture containing dNTPs $(0.5 \mathrm{mM}$ with final concentration $5 \mathrm{mM} \mathrm{MgCl}_{2}$ ), a molar excess of polyrA/oligodT $(4 \mu \mathrm{g} / 20 \mu \mathrm{L})$, and heparin $(10 \mu \mathrm{g} / 20 \mu \mathrm{L})$. The reactions were terminated by the use of 2 $\mu \mathrm{L}$ stop solution after a 3-min incubation at $37^{\circ} \mathrm{C}$ or $55^{\circ} \mathrm{C}$. Reaction products were immediately denatured by incubation at $95^{\circ} \mathrm{C}$ for $3 \mathrm{~min}$ and analyzed by electrophoresis in $14 \%$ polyacrylamide-urea gels. The amounts of the fully extended primer (" $F$ " in Figure 1) and the primer extending beyond the first stop sites (Figures 1 and 2) were determined by the phosphorimager analysis of the gels. The fidelity changes (Figure 1) were determined as described (27). Our purified and purchased MuLV reverse transcriptases showed a similar level of misincorporation in this assay.

\section{Kinetic Assay for Misinsertion Fidelity of MuLV Reverse Transcriptase}

A modification of the steady state kinetic assay of Boosalis et al. (2) was used to determine the misinsertion frequencies of the reverse transcriptases at 


\section{Research Report}

two different incubation temperatures. Reaction conditions were the same as described in the misincorporation assay (see above), except for the primer and the concentration of dNTPs. ${ }^{32} \mathrm{P}-1 \mathrm{a}-$ beled $\mathrm{C}$ primer (5'-CGCGCCGAATTCCCG-3') annealed to 40-mer RNA template $\left(5^{\prime}\right.$-AAGCUUGGCUGCAG AAUAUUGCUAGCGGGAAUUCG GCGCG-3') was extended by MuLV reverse trancriptase with increased concentrations of the correct dCTP $\left(2^{\prime}\right.$-deoxycytidine $5^{\prime}$-triphosphate) and one incorrect TTP (2'-deoxythymidine 5'triphosphate) at two different temperatures, $37^{\circ} \mathrm{C}$ and $55^{\circ} \mathrm{C}$ for $3 \mathrm{~min}$. The amounts of reverse transcriptase and incubation time were adjusted to yield extension of $10 \%-35 \%$ of the total labeled primer at the highest dNTP concentrations. Products were resolved in $14 \%$ polyacrylamide-urea gels and quantitated by phosphor-imaging analysis. The $k_{\text {cat }}$ and $\mathrm{Km}$ values were determined from Hanes-Woolf plots (11). The misinsertion fidelity, $f_{\text {ins }}$, was calculated at each temperature from the $k_{\text {cat }}$ and $\mathrm{Km}$ values as specified (2).

\section{Processivity Assay}

The reaction condition for measuring processivity requires a single round of primer extension (14). MuLV reverse transcriptase protein $(20 \mathrm{nM})$ was preincubated at $37^{\circ} \mathrm{C}$ or $55^{\circ} \mathrm{C}$ for 3 min with $5 \mathrm{nM}$ of either poly $(\mathrm{rA})$ (average size $=$ 260 nucleotides) (Amersham Pharmacia Biotech, Piscataway, NJ, USA) annealed to the 32P-labeled 20-mer oligodT or $1.7-\mathrm{kb}$ RNA template containing the coding sequence of the HIV1 reverse transcriptase gene annealed to the ${ }^{32} \mathrm{P}$-labeled 3305 reverse transcriptase primer (see Misincorporation Assay section) (14). Otherwise, reaction conditions were the same as described above. The extension reactions were initiated by adding the trap mixture containing dNTPs $(0.5 \mathrm{mM}$ with final concentration of $5 \mathrm{mM} \mathrm{MgCl}$ ), a molar excess of poly(rA)/oligodT $(4 \mu \mathrm{g} / 20 \mu \mathrm{L})$, and heparin $(10 \mu \mathrm{g} / 20 \mu \mathrm{L})$. The extension reactions were terminated by $2 \mu \mathrm{L}$ stop solution after a 3-min incubation at $37^{\circ} \mathrm{C}$ or $55^{\circ} \mathrm{C}$. Under this condition, the primer was extended only once during the incubation, as confirmed by the same two control reactions with or without the trap. The terminated processivity reaction and control reactions were analyzed by $8 \%$ urea-PAGE.

\section{RESULTS}

\section{Thermal Effect on Accuracy of MuLV Reverse Transcriptase}

To examine the effect of temperature on the accuracy of reverse transcription, we employed $(i)$ purified MuLV reverse transcriptase, which is known to be a high-fidelity reverse transcriptase, and (ii) a misincorporation assay that can measure both the incorporation of incorrect dNTPs and the extension of mismatched primer (21). First, the ${ }^{32} \mathrm{P}$ end-labeled matched primer (Figure 1A) annealed 40-mer RNA template was extended by reverse transcriptase in the presence of all four dNTPs or only three dNTPs. In the reactions with only three dNTPs, the incorrect dNTPs were incorporated at the sites where the deleted dNTPs should have been incorporated, called stop sites, and were extended by infidelity of reverse transcriptase. Therefore, in this misincorporation assay, the higher efficiency of primer extension beyond the stop sites (marked by “*” in Figure 1) reflected the lower fidelity of the reverse transcriptase protein $(13,14,21)$. We performed the misincorporation assay with

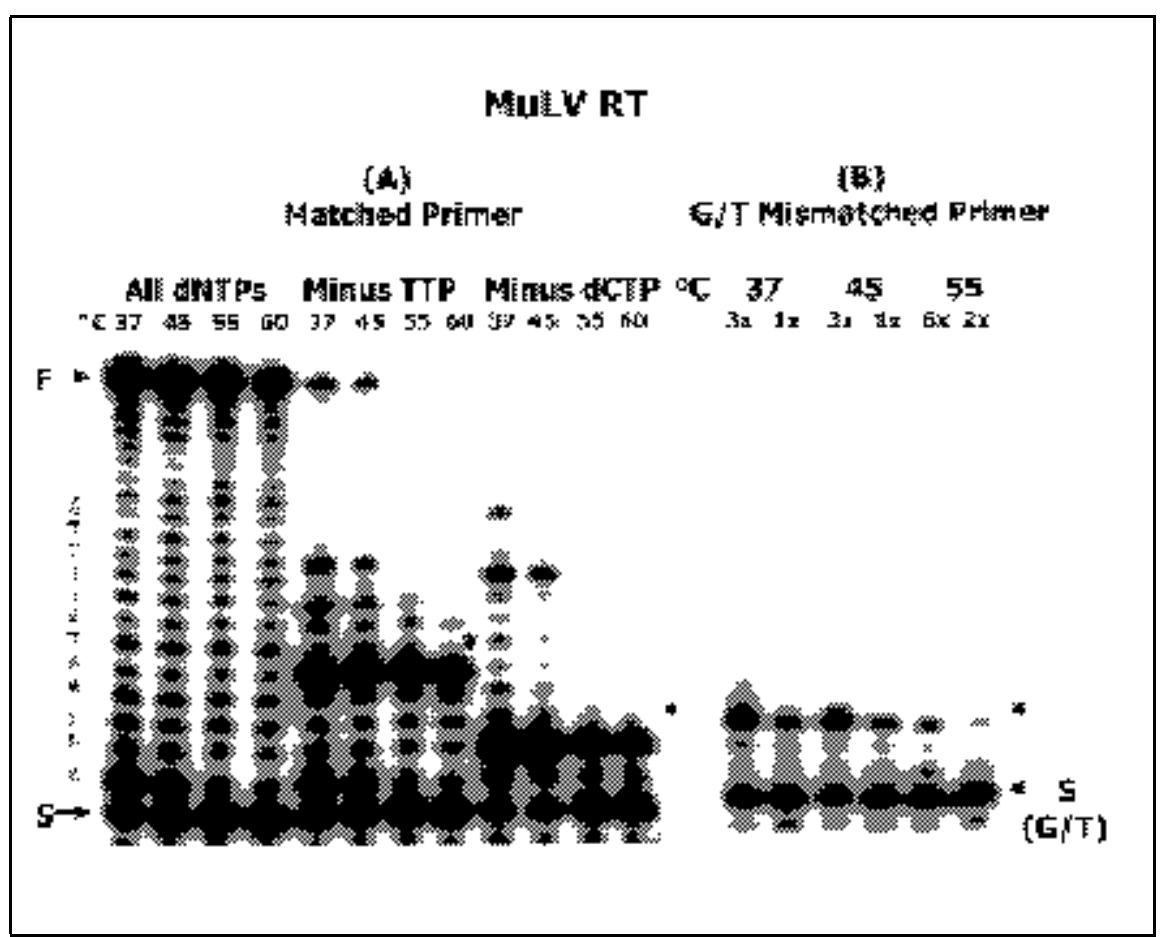

Figure 1. Thermal effect on fidelity of MuLV reverse transcriptase. (A) Misincorporation assay with matched primer: the 32P-labeled 17-mer matched primer ("S") annealed to a 40-mer RNA template was extended by MuLV reverse transcriptase protein $(15 \mathrm{nM})$ at $37^{\circ} \mathrm{C}, 45^{\circ} \mathrm{C}, 55^{\circ} \mathrm{C}$, and $60^{\circ} \mathrm{C}$ for $3 \mathrm{~min}$ in the presence of either all four dNTPs or only three complementary dNTPs (minus TTP and minus dCTP). As determined by amounts of the fully extended primer ("F") in all dNTPs, reverse transcriptase activity of MuLV reverse transcriptase was reduced to $65 \%$ at $55^{\circ} \mathrm{C}$. The sites with “*” indicate the stop sites where the deleted dNTPs would be incorporated into the reactions with only three dNTPs. In the assay with matched primer and only three dNTPs (A), the higher efficiency of elongation of terminated primer beyond the stop sites reflected the lower fidelity of the reverse transcriptase protein assayed. (B) Extension of mismached primer: the 32P-labeled 16-mer G/T mismatched primer ["S $(\mathrm{G} / \mathrm{T})$ "] annealed to a 40-mer RNA template was extended by MuLV reverse transcriptase protein at $37^{\circ} \mathrm{C}, 45^{\circ} \mathrm{C}$, and $55^{\circ} \mathrm{C}$ for $3 \mathrm{~min}$. In this reaction, 2-fold higher concentrations ( $6 \times$ and $2 \times$ ) of MuLV reverse transcriptase were used at $55^{\circ} \mathrm{C}$ to compensate for the reduction of the reverse transcriptase activity at $55^{\circ} \mathrm{C}$. The extension reactions with mismatched primer were performed in the presence of three dNTPs (minus dCTP), and the mismatched primer could be extended only up to the first stop site [“*” in (B)]. In the assay with mismatched primer (B), the higher efficiency of elongation of the mismatched primer reflected the lower fidelity of the reverse transcriptase protein. The reactions were analyzed by $14 \%$ denaturing gel electrophoresis. The DNA sequence of the first 12 nucleotides of the extended part of the primer is shown in (A). 


\section{Research Report}

Table 1. Thermal Effect on Misinsertion Fidelity of MuLV Reverse Transcriptase

\begin{tabular}{|c|c|c|c|c|c|c|}
\hline \multirow[b]{2}{*}{ Temperature } & \multicolumn{2}{|c|}{$\begin{array}{l}\text { Correct dNTP } \\
\text { (dCTP) }\end{array}$} & \multicolumn{2}{|c|}{$\begin{array}{l}\text { Incorrect dNTP } \\
\text { (TTP) }\end{array}$} & \multirow[b]{2}{*}{$f_{\text {ins }}{ }^{a}$} & \multirow[b]{2}{*}{$\begin{array}{c}\text { Fold } \\
\text { Changeb }^{b}\end{array}$} \\
\hline & $\begin{array}{l}\mathrm{Km} \\
(\mu \mathrm{M})\end{array}$ & $\begin{array}{l}k_{\text {cat }} \\
\left(s^{-1}\right)\end{array}$ & $\begin{array}{l}\mathbf{K m} \\
(\mu \mathrm{M})\end{array}$ & $\begin{array}{c}k_{\text {cat }} \\
\left(s^{-1} \times 10^{-3}\right)\end{array}$ & & \\
\hline $37^{\circ} \mathrm{C}$ & 0.15 & 0.22 & 24 & 1.2 & $3.4 \times 10^{-5}$ & $\times 1$ \\
\hline $55^{\circ} \mathrm{C}$ & 0.42 & 0.038 & $65^{c}$ & 0.03 & $5.1 \times 10^{-6}$ & $\times 6.7$ \\
\hline \multicolumn{7}{|c|}{$\begin{array}{l}\text { aMisinsertion fidelity, } f_{\text {ins }}=\left(k_{\text {cat }} / \mathrm{Km}\right) \text { with incorrect TTP } /\left(k_{\text {cat }} / \mathrm{Km}\right) \text { with correct } \\
\text { dCTP (2). } \\
\text { bFold difference }=f_{\text {ins }} \text { of } 37^{\circ} \mathrm{C} / f_{\text {ins }} \text { of } 55^{\circ} \mathrm{C} \text {. } \\
\text { CKm values of } 55^{\circ} \mathrm{C} \text { for incorrect TTP could not be determined accurately } \\
\text { because of little misinsertion (approximately } 5 \% \text { of the primer }) \text {, even with the } \\
\text { highest MuLV reverse transcriptase protein concentration. The } \mathrm{Km} \text { value at } \\
55^{\circ} \mathrm{C} \text { with TTP was calculated based on the difference of } \mathrm{Km} \text { values observed } \\
\text { with correct dCTP between } 37^{\circ} \mathrm{C} \text { and } 55^{\circ} \mathrm{C} \text {. }\end{array}$} \\
\hline
\end{tabular}

$15 \mathrm{nM}$ MuLV reverse transcriptase at four different temperatures: $37^{\circ} \mathrm{C}$, $45^{\circ} \mathrm{C}, 55^{\circ} \mathrm{C}$, and $60^{\circ} \mathrm{C}$. As seen in Figure $1 \mathrm{~A}$ with all of the dNTPs, the total amount of the fully extended product ("F" in Figure 1) was reduced to only $65 \%$ of normal when reactions were performed at $55^{\circ} \mathrm{C}$ rather than $37^{\circ} \mathrm{C}$. Thus, MuLV reverse transcriptase remains highly active at high temperatures. However, as seen in the reactions lacking TTP or dCTP (Figure 1A), the amount of extended product beyond the first stop sites (* in Figure 1), which was determined by phosphor-imaging analysis of the gel, was greatly reduced at $55^{\circ} \mathrm{C}$ as compared to $37^{\circ} \mathrm{C}$. Similar reduction of misincorporation was observed in reactions lacking dATP or dGTP (data not shown). To compensate for the slightly reduced reverse transcriptase activity at $55^{\circ} \mathrm{C}$, we performed the misincorporation assay with a higher reverse transcriptase concentration $(25 \mathrm{nM})$. Even with this com pensated amount of reverse transcriptase, a much lower amount $(5.3 \times)$ of the primer extension was observed at $55^{\circ} \mathrm{C}$ compared to $37^{\circ} \mathrm{C}$ (data not shown). We also used two commercially available MuLV reverse transcriptases in this assay, which showed similar levels of thermal effect on their fidelity (data not shown). These data indicate that an increase in temperature largely enhances the accuracy of DNA synthesis catalyzed by MuLV reverse transcriptase. It is likely that the improved accu- racy of reverse transcription at a high temperature is caused by the melting of the $3^{\prime}$ end of the primer.

\section{Thermal Effect on Extension of Mismatched Primer by MuLV Reverse Transcriptase}

The creation of a mutation during DNA synthesis consists of two sequential steps: $(i)$ incorporation of incorrect dNTPs and (ii) extension of the mismatched primer generated by misincorporation. In the misincorporation assay shown in Figure 1A, the extension of primer beyond the stop sites measured the capability of the reverse transcriptase proteins both to misincorporate and to extend mismatched primer. Next, we examined the capability of MuLV reverse transcriptase only to extend the mismatched primer (i.e., the second step of mutation synthesis). In this study, we used a 16-mer mismatched primer containing a G/T mismatch at the $3^{\prime}$ end of the primer that was annealed to a 40-mer RNA template. The primer extension reactions were performed with only three dNTPs (-dCTP in G/T-mismatched primer reactions). We used two different concentrations $(3 \times$ and $1 \times)$ of MuLV reverse transcriptase at $37^{\circ} \mathrm{C}$ and $45^{\circ} \mathrm{C}$, and 2 fold higher concentrations ( $6 \times$ and $2 \times$ ) of $\mathrm{MuLV}$ reverse transcriptase were used at $55^{\circ} \mathrm{C}$ to compensate for the reduction of reverse transcriptase activity at $55^{\circ} \mathrm{C}$. As seen in Figure $1 \mathrm{~B}, \mathrm{MuLV}$ reverse transcriptase showed an approximately 4-fold lower level of extension of the G/T-mismatched primer at $55^{\circ} \mathrm{C}$ than at $37^{\circ} \mathrm{C}$ or $45^{\circ} \mathrm{C}$, even with this compensated amount of reverse transcriptase. It is likely that the improved accuracy of reverse transcription at a high temperature could be caused by further melting of the unstable mismatched primer. However, Taq Pol (Applied Biosystems, Foster City, CA, USA), a thermo-stable DNA polymerase, can extend mismatched primer up to $70^{\circ} \mathrm{C}(10)$.

\section{Thermal Effect on Misinsertion Kinetics of MuLV Reverse Transcriptase}

Next, we employed a steady-state kinetic assay to measure the misinsertion fidelity $\left(f_{\text {ins }}\right)$ of MuLV reverse transcriptase protein at $37^{\circ} \mathrm{C}$ and $55^{\circ} \mathrm{C}$. The $f_{\text {ins }}$ value was calculated by two kinetic parameters, $k_{\text {cat }}$ and $\mathrm{Km}$, which indicate the capability of DNA polymerases to incorporate dNTPs (25). It was reported that $\mathrm{G} \rightarrow \mathrm{A}$ mutation, which can be made by the misinsertion of TTP instead of the correct dCTP during the RNA-dependent DNA polymerization step, is a predominant mutation spectrum during reverse transcription (3). Therefore, we measured the misinsertion fidelity for the $\mathrm{C}$ (correct) to $\mathrm{T}$ (incorrect) mutation using an RNA tem plate (Table 1). The $k_{\text {cat }}$ and $\mathrm{Km}$ values of MuLV reverse transcriptase with correct versus incorrect nucleotides were measured at $37^{\circ} \mathrm{C}$ and $55^{\circ} \mathrm{C}$ by a gel-based analysis and Hanes-Woolf equation (11). As shown in Table 1, and consistent with the misincorporation assay data, MuLV reverse transcriptase showed at least 6.7 times lower misinsertion frequency at $55^{\circ} \mathrm{C}$ than $37^{\circ} \mathrm{C}$. Catalysis $\left(k_{\text {cat }}\right)$ for misinsertion was largely reduced at $55^{\circ} \mathrm{C}$.

\section{Thermal Effect on Fidelity of HIV-1 Reverse Transcriptase}

HIV-1 reverse transcriptase is the most error-prone DNA polymerase among the known DNA polymerases (26). We tested whether the infidelity of HIV-1 reverse transcriptase is also affected by temperature changes. Both an RNA template encoding an HIV-1 viral 
genomic sequence and a 63-mer DNA template were used for this experiment. As seen in Figure 2A, the fidelity of HIV-1 reverse transcriptase with both RNA and DNA templates was largely enhanced at high temperatures with little loss of total reverse transcriptase activity (only a $20 \%$ reduction of HIV-1 reverse transcriptase activity at $55^{\circ} \mathrm{C}$ ). Similar reduction of misincorporation was observed in reactions lacking dCTP, dATP, or dGTP (data not shown). Therefore, this observation supports the notion of a universal thermal effect on the fidelity of reverse transcription.

\section{Thermal Effect on Processivity of Reverse Transcription}

We tested whether an increase in temperature, which could remove secondary structures of RNA template, enhances the processivity of reverse transcription. For this test, we used two RNA templates: $(i)$ heterogeneous RNA template encoding a (+) RNA strand sequence of the HIV-1 Pol gene and (ii) homogeneous poly(rA) template. The processivity assay requires a single round of primer extension; for this, a molar excess of cold poly(rA)/oligodT

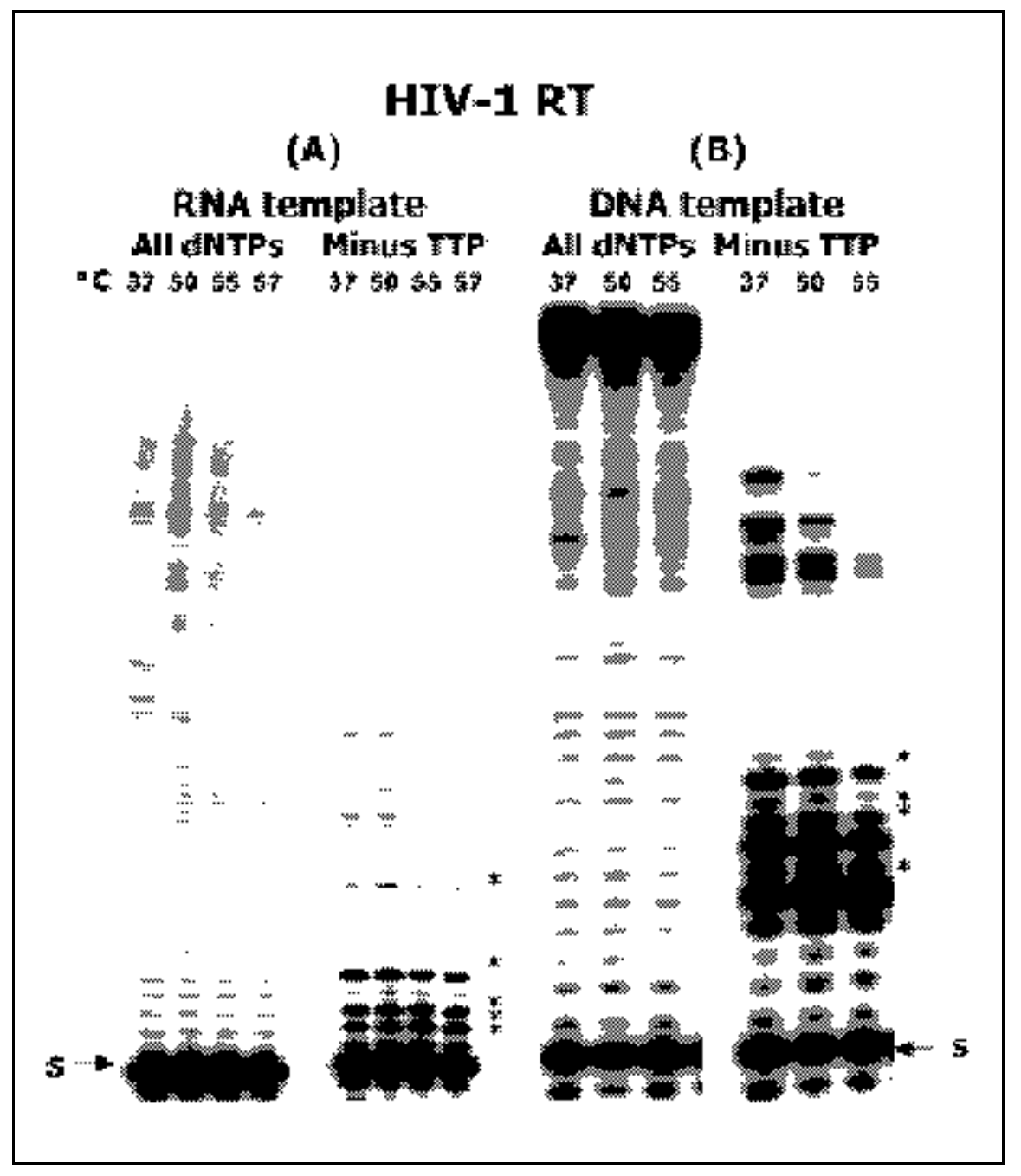

Figure 2. Thermal effect on fidelity of HIV-1 reverse transcriptase. (A) The 32P-labeled 21-mer matched 3305 primer ("S") annealed to a 1.7-kb-long RNA template encoding positive strand of HIV-1 Pol sequence was extended by HIV-1 reverse transcriptase at $37^{\circ} \mathrm{C}, 50^{\circ} \mathrm{C}, 55^{\circ} \mathrm{C}$, and $57^{\circ} \mathrm{C}$ for $3 \mathrm{~min}$, as seen in the extension reactions with all four dNTPs or only three complementary dNTPs (minus TTP). (B) The 3 P-labeled 17-mer matched primer ("S") annealed to a 63-mer DNA template was also extended by HIV-1 reverse transcriptase protein at $37^{\circ} \mathrm{C}, 50^{\circ} \mathrm{C}$, and $55^{\circ} \mathrm{C}$ for $3 \mathrm{~min}$, as seen in the extension reactions with all four dNTPs or only three complementary dNTPs (minus TTP). The first five (A) and four (B) stop sites were marked by “*”.

and heparin were used to trap free reverse transcriptase molecules to prevent multiple rounds of reverse transcription initiation (14). As seen in Figure 3A, reverse transcription of the heterogeneous HIV RNA template generated multiple pause sites, showing a higher band intensity at $37^{\circ} \mathrm{C}$ (marked by "*” and arrows). As seen in the control reactions (+Trap) of Figure 3, pre-incubation with the trap before primer extension com pletely prevented primer extension, indicating that the trap successfully sequestered free reverse transcriptase molecules. In the reaction without the trap, the primer was extended further, indicating a multiple round of initiation (data not shown). These two controls indicate a single round of reverse transcription in the processivity assay with the trap. As predicted, at $55^{\circ} \mathrm{C}$, the processivity of reverse transcriptase with the heterogeneous RNA template increased (Figure 3A). As seen in the reactions marked "Proc", many of the pause sites disappeared at high temperatures. This could be the result of an increased processivity at high temperatures. However, some pause sites were still observed (marked by "*” in Figure 3 ). The processivity with homogeneous poly(rA) template was also largely enhanced at high temperatures (Figure 3B). This observation indicates that an increase in temperature enhances processive DNA synthesis by reverse transcriptase in both heterogeneous and homogeneous RNA templates.

\section{DISCUSSION}

Various molecular analyses of RNAs, such as diagnostic detection and genotyping of viral RNAs, and quantitation of gene expression and cDNA libraries require a conversion of RNA molecules to more stable DNA molecules. This conversion step is enzymatically catalyzed by reverse transcriptase. Synthesized DNA copies are further amplified to obtain detectable and useful amounts of DNA molecules. How ever, several intrinsic aspects of reverse transcriptases interfere with reliable and efficient DNA synthesis from RNA. First, lack of $3^{\prime} \rightarrow 5^{\prime}$ proofreading activity in retroviral reverse transcriptases limits faithful DNA synthesis (26). 
Because mutations created during the reverse transcription step of RT-PCR are delivered to the final products to be analyzed, infidelity of reverse transcription is a major problem in RNA analysis. Second, RNA templates intrinsically form various types of secondary structures, which can stall translocation of the RT/dNTP/T-P ternary complex during reverse transcription $(4,15)$. This limits the efficiency of full-length DNA synthesis. As observed in previous studies with other DNA polymerases, pause sites are mutational hot spots because of high mutation probability during the first dNTP incorporation (8).

The enhancement of accuracy and processivity of reverse transcription is essential to the reliable and efficient analysis of RNA. In this study, we demonstrated that accuracy and processivity of reverse transcription are greatly enhanced at high temperatures. It is possible that the thermal effect on the fidelity of reverse transcription could be because of instability of mismatches at the $3^{\prime}$ end of the primer, which can be generated by incorporation of incorrect dNTP (misinsertion). In other words, $3^{\prime}$ mismatches can melt further, generating multiple mismatches at the $3^{\prime}$ end of the primer. Most DNA polymerases, including reverse transcriptases, have a largely reduced capability to extend such mismatched primers. However, the thermostable DNA polymerase, Taq Pol, can extend mispaired primers efficiently up to $70^{\circ} \mathrm{C}$ (10). Presumably, Taq Pol might have evolved the ability to extend the mismatched primers that will be constantly generated in extreme host environments (i.e., high temperature). Other factors that might be affect-

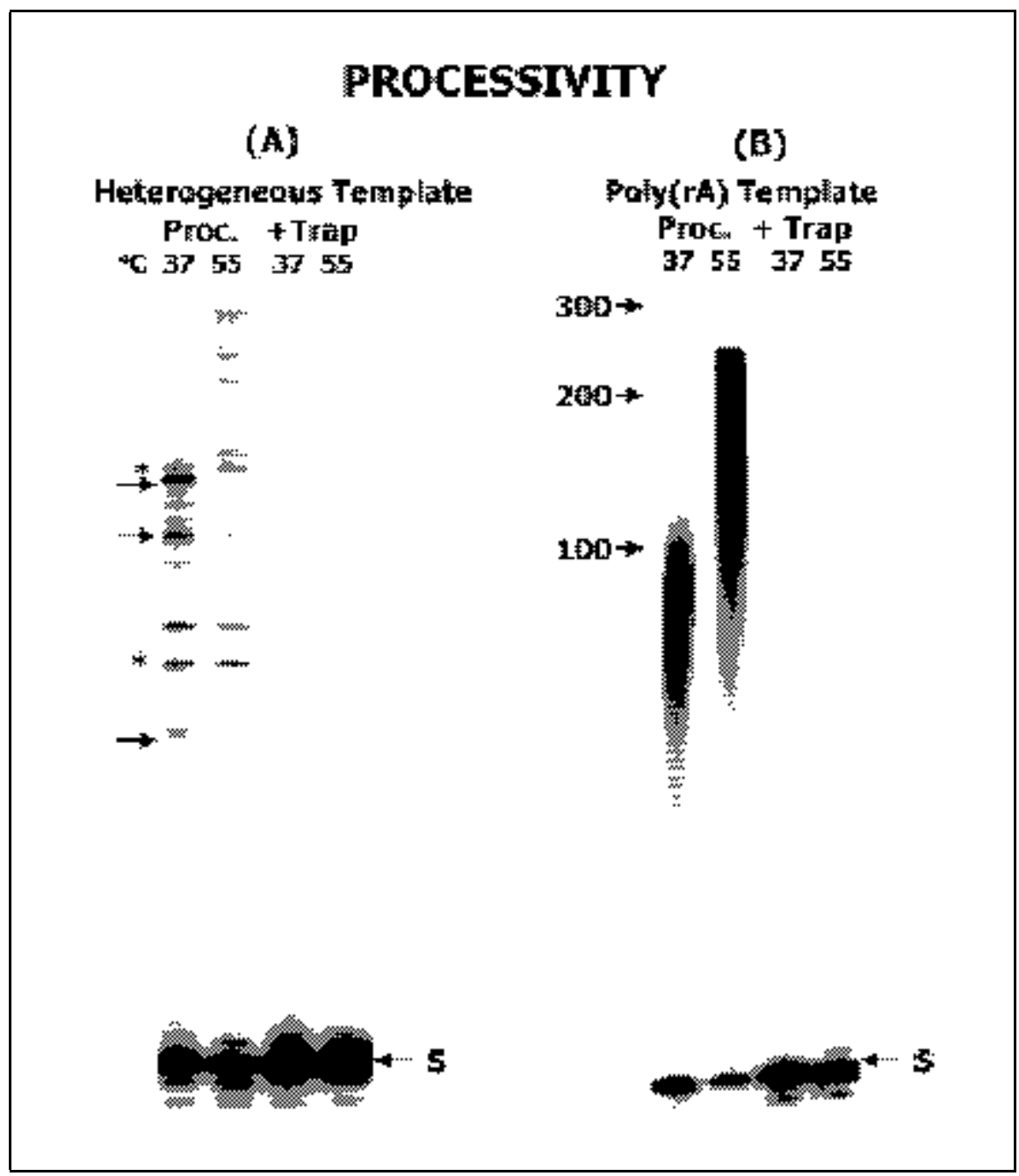

Figure 3. Processivity of MuLV reverse transcriptase proteins with (A) heterogeneous and (B) homogeneous RNA templates. (A) Heterogeneous RNA template encoding an HIV-1 Pol sequence, annealed to the 3 P-labeled 21-mer 3305 primer, and (B) Poly(rA) template annealed to the 32P-labeled 21mer oligodT were used in this processivity assay. Processivity (Proc): two template-primers (T/Ps) were first preincubated with MuLV reverse transcriptase proteins at $37^{\circ} \mathrm{C}$ or $55^{\circ} \mathrm{C}$ for $3 \mathrm{~min}$, and then the extension reactions were initiated by adding trap mixture containing dNTPs, a molar excess of poly(rA)/oligodT, and heparin at $37^{\circ} \mathrm{C}$ or $55^{\circ} \mathrm{C}$ for $3 \mathrm{~min}$. This condition allowed only a single round of primer extension by reverse transcriptase as confirmed by two control experiments (+ Trap and -Trap). +Trap: RNA T/Ps were first pre-mixed with the trap mixture, and the extension reactions were initiated by adding $\mathrm{MuLV}$ reverse transcriptase protein at $37^{\circ} \mathrm{C}$ or $55^{\circ} \mathrm{C}$ for $3 \mathrm{~min}$. This condition blocked reverse transcriptase binding to the labeled T/Ps and extending the primer, supporting a single round of primer extension in the processivity reaction. In addition, RNA T/Ps were also pre-mixed with reverse transcriptase proteins, and then the extension reactions were initiated by only dNTPs without trap (-Trap control) at $37^{\circ} \mathrm{C}$ or $55^{\circ} \mathrm{C}$ for $3 \mathrm{~min}$. This condition allowed multiple rounds of primer extension by reverse transcriptase proteins, generating more and much longer extended products (data not shown). All reactions were analyzed by $10 \%$ denaturing gel electrophoresis. The pause sites sensitive to temperature were marked by arrows, and the pause sites insensitive to temperature were marked by “*”. 
ed by temperature changes, such as structure and kinetics of reverse transcriptases, could also influence the accuracy of reverse transcription.

It has been demonstrated that various RNA template sequences forming secondary structure interfere with processive DNA synthesis from RNA molecules. For example, HIV-1 5' transactivation response region (TAR) can form a stable stem loop secondary structure (15). Several biochemical studies showed that this RNA secondary structure terminates DNA synthesis catalyzed by HIV-1 reverse transcriptase $(4,15)$. Relatively local minor structures can also contribute to the termination of processive DNA synthesis. These secondary structures are stabilized by lim ited basepairing between nucleotide sequences encoded in RNA template, which can be easily resolved by an increase in temperature. The elimination of the pause sites and enhanced processivity at high temperatures support this prediction (Figure 3A). It is also possible that the equilibrium of dNTPs may become favorable for the processive DNA synthesis at high temperatures.

In summary, this study uses temperature as a biochemical element that can be immediately applied to various types of biological assays for RNA molecules, and the quality of these RNA analyses will be largely enhanced by the adoption of this biochemical element.

\section{ACKNOWLEDGMENTS}

We thank Dr. Stephen Dewhurst and Dr. Daksha Patel for critical reading of the manuscript and Dr. Michael Emerman for providing us with the plasmid encoding the MuLV gene. This work was supported by National Institutes of Health grant no. R29-GM55500.

\section{REFERENCES}

1.Bieche, I., C. Nogues, V. Paradis, M. Olivi, P. Bedossa, R. Lidereau, and M. Vidaud. 2000. Quantitation of hTERT gene expression in sporadic breast tumors with a real-time reverse transcription-polymerase chain reaction assay. Clin. Cancer Res. 6:452-459.

2.Boosalis, M.S., J. Petruska, and M.F. Goodman. 1987. DNA polymerase insertion fidelity. Gel assay for site-specific kinetics. J. Biol.
Chem. 262:14689-14696.

3.Cheynier, R., S. Gratton, J.P. Vartanian, A. Meyerhans, and S. Wain-Hobson. 1997. $\mathrm{G} \rightarrow \mathrm{A}$ hypermutation does not result from polymerase chain reaction. AIDS Res. Hum. Retroviruses 13:985-986.

4.DeStefano, J.J., R.G. Buiser, L.M. Mallaber, P.J. Fay, and R.A. Bambara. 1992. Parameters that influence processive synthesis and site-specific termination by human immunodeficiency virus reverse transcriptase on RNA and DNA templates. Biochim. Biophys. Acta 1131:270-280.

5.Engelbrecht, S., T.L. Smith, P. Kasper, E. Faatz, M. Zeier, D. Moodley, C.G. Clay, and E.J. van Rensburg. 1999. HIV type 1 V3 domain serotyping and genotyping in gauteng, mpumalanga, kwaZulu-natal, and western cape provinces of South Africa. AIDS Res. Hum. Retroviruses 15:325-328.

6.Foley, K.P., M.W. Leonard, and J.D. Engel. 1993. Quantitation of RNA using the polymerase chain reaction. Trends Genet. 9:380385.

7.Freeman, W.M., S.J. Walker, and K.E. Vrana. 1999. Quantitative RT-PCR: pitfalls and potential. BioTechniques 26:112-122.

8.Fry, M. and L.A. Loeb. 1992. A DNA polymerase alpha pause site is a hot spot for nucleotide misinsertion. Proc. Natl. Acad. Sci. USA 89:763-767.

9.Hagen-Mann, K. and W. Mann. 1995. RTPCR and alternative methods to PCR for in vitro amplification of nucleic acids. Exp. Clin. Endocrinol. Diabetes 103:150-155.

10.Huang, M.M., N. Arnheim, and M.F. Goodman. 1992. Extension of base mispairs by Taq DNA polymerase: implications for single nucleotide discrimination in PCR. Nucleic Acids Res. 20:4567-4573.

11.Kamath-Loeb, A.S., A. Hizi, H. Kasai, and L.A. Loeb. 1997. Incorporation of the guanosine triphosphate analogs 8-oxo-dGTP and 8NH2-dGTP by reverse transcriptases and mammalian DNA polymerases. J. Biol. Chem. 272:5892-5898.

12.Kim, B. 1997. Genetic selection in Escherichia coli for active human immunodeficiency virus reverse transcriptase mutants. Methods 12:318-324.

13.Kim, B., T.R. Hathaway, and L.A. Loeb. 1998. Fidelity of mutant HIV-1-1 reverse transcriptases: interaction with the single-stranded template influences the accuracy of DNA synthesis. Biochemistry 37:5831-5839.

14.Kim, B., J.C. Ayran, S.G. Sagar, E.T. Adman, S.M. Fuller, N.H. Tran, and J. Horrigan. 1999. New human immunodeficiency virus type 1 reverse transcriptase (HIV-1-1 RT) mutants with increased fidelity of DNA synthesis: accuracy, template binding, and processivity. J. Biol. Chem. 274:2766626673.

15.Kim, J.K., C. Palaniappan, W. Wu, P.J. Fay, and R.A. Bambara. 1997. Evidence for a unique mechanism of strand transfer from the transactivation response region of HIV-1. J. Biol. Chem. 272:16769-16777.

16.Klarmann, G.J., C.A. Schauber, and B.D. Preston. 1993. Template-directed pausing of DNA synthesis by HIV-1 reverse transcriptase during polymerization of HIV-1 sequences in vitro. J. Biol. Chem. 268:9793-9802.

17.McGinniss, M.J., D.H. Brown, L.W. Burke, J.T. Mascarello, and M.C. Jones. 1997. Ring chromosome $\mathrm{X}$ in a child with manifestations of Kabuki syndrome. Am. J. Med. Genet. 70:37-42.

18.Metcalf, T.G., J.L. Melnick, and M.K. Estes. 1995. Environmental virology: from detection of virus in sewage and water by isolation to identification by molecular biology - a trip of over 50 years. Annu. Rev. Microbiol. 49:461-487.

19.Nakamura, S., S. Katamine, T. Yamamoto, S.K. Foung, T. Kurata, Y. Hirabayashi, K. Shimada, S. Hino et al. 1993. Amplification and detection of a single molecule of human immunodeficiency virus RNA. Virus Genes 7:325-333.

20.Peterson, L.A., M.R. Brown, A.J. Carlisle, E.C. Kohn, L.A. Liotta, M.R. EmmertBuck, and D.B. Krizman. 1998. An im proved method for construction of directionally cloned cDNA libraries from microdissected cells. Cancer Res. 58:5326-5328.

21.Preston, B.D., B.J. Poiesz, and L.A. Loeb. 1988. Fidelity of HIV-1 reverse transcriptase. Science 242:1168-1171.

22.Skalka, A.M. and S.P. Goff. 1993. Reverse Transcriptase, p. 1-4. CSH Laboratory Press, Cold Spring Harbor, NY.

23.Schiff, E.R., M. de Medina, and R.S. Kahn. 1999. New perspectives in the diagnosis of hepatitis C. Semin. Liver Dis. 19:3-15.

24.Sunday, M.E. 1995. Differential display RTPCR for identifying novel gene expression in the lung. Am. J. Physiol. 269:273-284.

25.Walker, K.B. 1998. Detection and analysis of cytokine mRNA in tissues and cell lines. J. Immunol. Methods 212:113-123.

26.Williams, K.J. and L.A. Loeb. 1992. Retroviral transcriptases: error frequencies and mutagenesis, p. 165-180. In J.J. Holland (Ed.), Current Topics in Microbiology and Im munology: Genetic Diversity of RNA Viruses. Spriner-Verlag, Berlin Heidelberg.

27.Wisniewski, M., C. Palaniappan, Z. Fu, S.F. Le Grice, P. Fay, and R.A. Bambara. 1999. Mutations in the primer grip region of HIV reverse transcriptase can increase replication fidelity. J. Biol. Chem. 274:28175-28184.

28.Zekri, A.R., A.A. Bahnassy, S.M. Shaarawy, O.A. Mansour, M.A. Maduar, H.M. Khaled, and O. El-Ahmadi. 2000. Hepatitis $\mathrm{C}$ 0virus genotyping in relation to neu-oncoprotein overexpression and the development of hepatocellular carcinoma. J. Med. Microbiol. 49:89-95.

Received 8 June 2000; accepted 3 November 2000.

\section{Address correspondence to:}

Dr. Baek Kim

601 Elmwood Avenue

Box 672

Department of Microbiology and Immunology

University of Rochester Medical Center

Rochester, NY 14672, USA

e-mail: baek_kim@urmc.rochester.edu 